\title{
The Role of Leaders in Building Islamic Work Ethos
}

\author{
MUHARDI \\ Fakultas Ekonomi dan Bisnis, Universitas Islam Bandung, Jalan Tamansari No. 1 Bandung \\ email: muhardi.z66@gmail.com
}

\begin{abstract}
The background of this research is the well-practiced Islamic working ethos in Universitas Islam Bandung as an Islamic based educational institution. It drives a strong motivation to acknowledge the subject behind the implementation success. Based on that, the primary goals of this research are to analyze the employees' working ethos in the Islamic based educational institution and the role of middle-line and first-line leaders to form the employees' working ethos. This research used a case study method of descriptive approach with employees of Universitas Islam Bandung's Post-Graduate Program as the respondents. The primary data were collected through interview, meanwhile secondary data were gathered from administration documents. The result reveals that the employees working ethos is on a decent level by the involvement of Ruhul Islam existence. There is a significant role of middle-line and first-line leaders in building the employees' working ethos, which are respectively dominated by legitimate power and referent power utilization.
\end{abstract}

Keywords: islamic working ethos, leaders, ruhul islam.

\section{Introduction}

Islam has an ideal concept of working. In Islam, working is an essential form of worship, so that it would bring benefits either for the workers themselves and the people connected, directly or indirectly with the work itself. Furthermore, Islam strictly disagrees with laziness and people who are dependent on the help of others, particularly in providing daily economic needs.

In an Islamic based educational institution that upholds Ruhul Islam or the core spirit of Islam, every aspect connected with work life should be able to reflect the Islamic values. The application of Islamic soul in working will be able to bring out phenomena such as high working spirit, high motivation to practice their best in work, and the formation of a favorable situation in social life inside the working environment as a supporting aspect to reach institutional goals. Besides that, it is critical for Islamic based educational institution to be able to drive Islamic activities implementation as a part of educational system.

In the effort to obtain harmony between
Islamic values and various educational policies that have been set, it is vital for the leaders to apply these values internally, especially for those who play as stakeholders in policy making and application process. The leadership system in the Islamic based educational institution, which includes the middle-line and the first-line leaders, never cease to involve themselves directly to reinforce employees working ethos.

Middle-line leaders hold an important role in the employees' daily working life and the application of Islamic working ethos in an Islamic based educational institution. The implementation of concepts related to Islamic working ethos will be more difficult if the employees are not embedding Islamic values internally. The application of Islamic values in the employees' working life supports the practice of Islamic based educational institution employees' working ethos. The existence of Ruhul Islam brings the employees' sincerity and integrity to perform their best in fulfilling their working obligations in any given situation.

Identification of Islamic working ethos as

Received: April 28, 2017, Revision: September 30, 2017, Accepted: December 07, 2017

Print ISSN: 0215-8175; Online ISSN: 2303-2499. DOI: http://dx.doi.org/10.29313/mimbar.v33i2.2414.310-318

Accredited B based on the decree No.040/P/2014, valid on February, 18, 2014 until February, 18, 2019. Indexed by DOAJ, Sinta, IPI 
a form of educational institution manifestation, or in this case the Post-Graduation Program of Universitas Islam Bandung's ideology, is the existence of several indicators such as honesty, loyalty, responsibility, initiative, etc. The presence of these factors is an active indication concerning the practice of Islamic working ethos. Therefore, it is important to acknowledge the condition of the employees working ethos in the Post-Graduate Program of Universitas Islam Bandung as one of the Islamic based educational institutions. The indicated state has generated high motivation to conduct research and further study about the employees' working ethos in an Islamic based educational institution and the role of middle-line and first-line leaders in building the employees' working ethos.

\section{Research Method}

This research used a case study method with descriptive approach limited to a sample unit which also plays as the population. This method collects information from population unit to acknowledge and explain the various phenomena occurs through the research. The sample units are the employees of Universitas Islam Bandung's Post-Graduate Program. The middle-line leader in this research refers to the Director and first-line leaders are Head of Study Programs.

In this research, the existence of two kinds of data are imminent; primary data were taken through interview with the employees and documentation, and secondary data were obtained from Universitas Islam Bandung's Post-Graduate Program administration documentation and relevant literatures. Analysis tool utilized in this research is qualitative descriptive.

\section{The Islamic Leadership and Its Role in Employees' Work Ethos}

Human capital plays an integral part in driving employees towards institutional success (Badriyah and Noermijati, 2015). The employees are human resources that need to have work ethos. In this case, the definition of ethos is an effort of building personal credibility (Baldwin et al., 2013). Islamic working ethos is the working personality or character of a Muslim individual or group. Similar to that, Tasmara (2004) defines ethos as customs, culture, and every valuation systems adopted by a person or a group of individuals.

The working environment affected by a leadership system in correspondence with Islamic values will assist the formation of Islamic working ethos. Putri and Gustomo (2012) stated that leaders play an essential role to create a condition where the employees will be able to enhance their capacity and to maintain organizational culture condition so that it would stay on a decent level. The finding is similar to Sumual's (2015), which mentioned that a competent leader would be able to direct employees to achieve organization's goals.

Spiritual intelligence in working environment is one of the most important forms of worship (Nida, 2013). The concept of working in Islam (called 'amal) is far broader and has different characteristics and objectives than that understood in the Western economic tradition (Possumah et al., 2013). Meanwhile, according to another opinion, all forms of activities (mundane work, including trade) which are done with sincere intentions are permissible to be turned into worship (Lauselang et al., 2016). According to Hasan (2005), working ethos in Islam is not only material but has more than that; it contains a worship or spiritual value. Based on these opinions, we can say that in Islam working is not only a way to fulfill economic needs but also a form of piety and thankfulness for all the gifts from Allah Subhanahu Wa Ta'ala. Considering that working is a kind of worship, every activity should be carried out with sincerity which would further enhance the working quality optimally.

Even though the experts have defined several dimensions of working ethos in various definitions, Muslim workers should possess Islamic working ethos as a manifestation of their work principles to produce optimum performance. In parallel with that, the required, implemented, and cultivated exemplary, including at work is the characters of Siddiq, Amanah, Tabligh, Fathonah (Aziz, 2008). Siddiq means being true, Amanah means being honest, Tabligh implies the effort to convey what must, and Fathonah means intelligent.

The role of middle-line and first-line leaders in building the Islamic working ethos has a high urgency in the form of motivation or the ability to create an Islamic atmosphere inside the working environment. Without a direct role of the leaders in both management levels inside the institution, various programs in realizing Islamic working ethos development will be a lot more complicated. It strengthens 
Elgelal and Noermijati's (2014) argument that there is a high correlation between methods utilized by the leaders to lead the employees and the employees' performance.

A leader also means to become a role model for his subordinates (Dewi and Rachmawati, 2014). Leaders must be able to provide high motivation for their subordinates to apply specific values in their work. By giving a motivation, these leaders must be able to exercise several types of powers in their leadership systems such as reward power, legitimate power, referent power, expert power, coercive power (Baldwin et al., 2013; McShane and Von Glinow, 2015), and personal power (Newstrom, 2015). Meanwhile, Robbins and Judge (2015) further divide those types of powers into two portions, which are; formal power that consists of coercive power, reward power, and legitimate power; and personal power, which includes expert power and referent power. Moreover, Daft (2012) classifies powers with a more profound opinion based on their sources. The classifications are position power that covers legitimate power, reward power and coercive power; personal power, which consists of expert power and referent power; and the other source of power which are personal effort and network of relationships and information. This research will focus on the overall power of the leaders which usually indicated in Post-Graduate Program of Universitas Islam Bandung.

The application of reward power by a leader is a form of negative sanctions or compensations avoidance due to the employees' errors (McShane and Von Glinow, 2015). Reward power focuses more on positive benefits towards the employees, as rewards for various achievements achieved by the employees in their work. This type of power intends to motivate the employees to involve in a more real competition to obtain various kinds of reward such as salary increments, bonuses, promotion, etc. In the application of reward power, a negative sanction is uncommon because the employee is usually involved in a high-level competition that would create a higher line of working standard.

Legitimate power possesses more substantial discretion than reward power (Robbins and Judge, 2015). In legitimate power, the recognition of leaders' authority comes from either the leaders themselves or their subordinates. Based on that, this kind of power contains an urge to push the employees to obey any regulations established by the leaders. Legitimate power itself is a power of formal authority provided by the institution towards their leaders to organize and utilize available resources and reflects the leaders' position in the organization.

Referent power is more associated with exemplary individuals that become role models instead of the positions of the people (Baldwin et al., 2013). This type of power expects the leaders to have an ability to become a role model for the employees in every aspect of work. Furthermore, in the application of this power, it is prevalent that the employees not only follow the working behavior of the leaders, but also tend to duplicate the smallest actions of the leaders. In the working world, referent power has more relations with respect and a decent relationship between the leaders and the employees.

Next is the expert power. It emerges internally from the leaders due to the particular expertise that has general recognition (Newstrom, 2015). This type of power is critical for a leader because it has a close relationship with the ability of the leaders to face a situation that requires particular expertise to take a decision. Without the involvement of expert power, it would be harder for the leaders to optimize institution's targets achievement.

Coercive power has the opposite approaches to reward power, where the leaders choose to benefit their power to give or recommend a sanction for violations of rules or principles of the managers (Daft, 2012). Leaders, who use this type of power, tend to find it more difficult for them to appreciate employee's achievements. Besides that, the employees' negative perception towards their leaders is stronger than the employees' positive perception.

The application of those types of power will depend on the ability of the leaders since they will always bring either positive or negative impact, which depends on the leaders' strength in leading an organization. The stronger the leaders, the more active the organization will become. Otherwise, the weaker the leaders, the more ineffective the organization will be. Similarly, Mihrez and Armanu (2014) emphasized that the leaders' positive behaviors would bring positive and significant impacts towards employees' performance, which means that a strong 
leader would result in a decent employees' performance.

It is crucial for leaders to form a good communication style, especially leaders in an educational institution (Yuningsih and Mulyana, 2017). It is also important for leaders to always adjust their leading style. If a leader faces a situation where he needs to loosen his leadership, then he should be able to change his leadership style automatically. A leader also needs to involve himself in the activities he has planned before to increase employees' understanding of the importance of the participation value. As it mentioned by Diefenbach (2015), a leader must possess good intelligence regarding his employees' social condition, be open and participative, and able to act and think based on any conditions in his presence.

There are three levels of leadership in an institution, which are top leaders, middle-line leaders, and first-line leaders (Schermerhorn and Bachrach, 2015). Senior or top leaders have more function as policymakers to organize the institution. Middle-line leaders who work on a more limited scope than the top leaders do, plays the role as executors of the policies. Meanwhile, first-line leaders act as controllers and supervisors of the policies implementation because they often directly connect with the employees and have a better view of the situation in the field.

\section{The Employees' Islamic Working Ethos in Islamic Based Educational Institution}

The employees' Islamic working ethos in Islamic based educational institution, in this case, Universitas Islam Bandung Post-Graduate Program, is one of the major characteristics that has become the employees' working culture. The basics of this finding are the existence of several indicators that form the employees' working ethos. Before elaborating about working ethos formation, we will previously explain the respondents' characteristics of this research which observed from their age. Most of the employees are 26 to 45 years old. Number of respondents over 45 years old were few compared to the younger ones. Next indicator is the employees' working period. The employees have been working for 5 to 20 years, and their education level is ranging from high school graduate to scholars.

The result of this research reveals that the employees' discipline is in a fair condition which reflected in their work-time from 08:00 am until 16:00 pm. Although several respondents reside outside the city and it is quite a distance from home to the office, work time fulfillment has not been a problem for the employees. The institution used computerized absence to report employees' work time fulfillment. It is an obligatory for them to report their presence using the machine every morning and at the end of their working hour so that the institution could detect the employees who came late. Absences recording will be unavailable after the work time begins and the institution will consider late the employees who came after that time. However, a sanction over this matter is low and indicates that employees' late arrivals are minimal. This situation is in line with the institution's slogan: "a disgrace, an employee that arrives late" and it is subjected to all the employees.

Discipline in working time is also visible through proper time-off utilization. To take a break within a working hour is uncommon for the employees. They can use their break time for praying, having lunch, and taking a rest. Based on that, we can say that the employees have maximized their working time utilization. However, rewarding system related to working hours discipline has not reached an optimum level and tend to be more personal. The lack of proper reward from institution brings out various responses from the employees and forms an assumption that appreciation only comes from the leader as a private valuation and does not have anything to do with the institution. Institution assessment is provided once a year in the form of a formal work valuation list known as DP3 (Daftar Penilaian Pelaksanaan Pekerjaan) that contains every valuation connected with the employees working results. Based on the finding, it is important for the institution to increase their attention so that the employees can be more enthusiastic in doing their job.

The positive working culture of the employees in this institution creates a performance with no complaints or no laziness. The employees execute their job assignments with great sincerity and honesty. Because of that, the perception of the employees on their job assignment becomes positive. Moreover, since they consider working as a fun thing to do, it would be easier for them to finish their job. There is also minimum level of complaint comes from their clients, either externally or internally. Internal clients are the leaders and lecturers; external clients are 
the students. This minimum level of complaint has strengthened the previous statement that the employees of this educational institution are on a decent level.

The employees' sincerity and honesty, time efficiency, accuracy, minimum complaint internally and externally, and a satisfying work completion indicates that the employees' performance has reflected a proper application of Ruhul Islam (Islamic values) in practicing their job. In other word, the result of Ruhul Islam application in this institution is the creation of work effectiveness. Besides that, Islamic working ethos is not only visible through performance but also reflected in the employees' behaviors. Practices indicated from the employees are courtesy and hospitality in performing their service towards their leaders, lecturers, and the students.

The conduction of Islamic working ethos concept by Universitas Islam Bandung Post-Graduate program as an Islamic based educational institution that adopts Ruhul Islam as its foundation forms the employees to become an effective and efficient human being in working. The employees in this institution possess a decent perspective on how to become a good servant based on Islamic values. Indications of this finding are the existence of excellent service accompanied by social awareness, adequate knowledge, and outstanding working skills. Besides that, during their service, the employees always involve their Islamic identity by showing great patience, hospitality, accommodative, honest and trustworthy.

The employees' devotion to performing their best effort and the urge to help others has become familiar aspects in the institution. It will push the employees internally to always be helpful for their customers, in this case, are the leaders and the students, so that their work result can be maximized and reach the total achievement. Incomplete services are an uncommon thing to happen, and if it happens, normally it is not because of the employees' low service swiftness. Working hour limitation and requests that comes at the end of their working hour is the main factors that create the existence of unfinished tasks. However, the incomplete work always becomes a priority to minimize job accumulation so it would not happen too often.

Besides that, there is also a decent family atmosphere amongst the employee. The indication of employees' routine to give attention towards one another and each other is the regularity of greetings, asking about each other's news, visiting those who ill/ sick and other form of attention. Moreover, act of attention/giving usually have more connection with subjects that are more technical and work-related. It is common that the employees with longer working time help the employees with shorter working time in technical issues relating to their jobs, such as routine task, practice, and bureaucracy lines, even though this institution also provides numerous training for the employees in various subjects. The closeness between the employees has also created a decent level of cooperation, especially when they do a collaborative work that pushes them to cooperate with each other to achieve institutional goals.

\section{The Role of Middle-line and First- line Leaders in Building Employees' Islamic Working Ethos}

Besides internal motivation, the figure of leaders in this institution has become an important indicator to form employees' behavior by giving a positive example, such as arriving at work on time and appropriate job completions which never exceeds targeted time. Besides that, the leaders often motivate the employees by involving them in a nonformal working method discussion or giving a correction on their job to improve the quality of their work. The initiation of building Islamic working ethos also comes from both leaders in an official form by conducting a weekly religious study and informally inserting various study about many religious aspects related with working ethos. These activities aim to improve the employees' understanding of how Islam views work and how to do it in Islamic perspective. To expand the employees understanding of the leaders' role in both levels in this institution, we will further discuss activities that can improve Islamic working ethos in this institution.

From the perspective of middle-level management, Islamic working ethos drivers in this institution are expertise, legitimate, reward power, and the application of punishment for disobedience. The domination of middle-level management in improving Islamic working ethos focuses on how to become a good example. Meanwhile, the legitimate power was taken by policies or rules and routine activities application. The application of the first strategy is to push employees working hour punctuation by installing various motivational props such as banner or poster 
contained recommendations to avoid late arrivals. Meanwhile, if the employees happen to arrive late, the punishment is in the form of private reprimand. The reason to give private reprimand is that they would not feel insulted and mentally motivated to avoid repeating the same mistake.

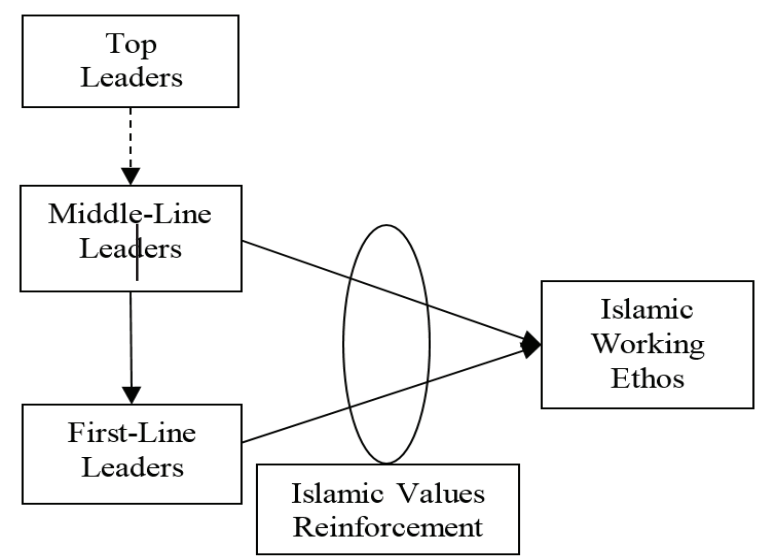

Figure 1. Model of Leaders' Role in Building Islamic Work Ethos

The next policy is to apply several routine activities such as studies and lectures about religious values. Even though the main topics are religion-related, they usually have connections with efforts to improve the employees' Islamic working ethos. Examples of several topics in these activities are: the understanding of working in Islamic perspective, work practice based on Islam as a religion, high working performance, and the importance of honesty in working. These Islamic studies applications are not only discussing religious subjects but also in a more general context. The leaders implant these improvement ideas during break time such as lunchtime with the mixture conversation of various instructions and directions to improve working quality, ideal working knowledge in Islamic perspective, and other knowledge that can support working performance.

First-line leaders apply Islamic working ethos encouragement by setting exemplary obedience toward the employees in the rules made by the institutions. First-line leaders' role to improve working ethos implementation in this educational institution is by involving themselves in many activities formed by middle-line leaders to drive employees' involvement indirectly due to their concern about those activities. Besides that, the firstline leaders also play an important role as supervisors and support system to increase the activities' chance to produce a successful outcome. This involvement and support are accompanied by supervision function, which is not only applied formally, such as reprimand based on work errors, but also nonformally approach such as lunch talk. Both aspects have been ideal ways for the firstline leaders to insert various understanding about the importance of Islamic working ethos application by the employees for the success of this institution.

To correctly apply Ruhul Islam, this educational institution pushes the leaders on both management levels and make it obligatory for the leaders to accept it as a form of assignment to organize, implement, and control these Ruhul Islam formation activities through proper supervision and evaluation. Both middle and first-line leaders coordinate these activities by creating various concepts to improve employees' working ethos, such as Islamic study activities. In practice, the implementation step is the insertion of applied concepts into several activities and furthermore continued with controlling process where every assessment is done by checking Islamic ethos activities valuation result. If one of these activities is not effective, a replacement is set to achieve optimum employees' Islamic working ethos development.

The leaders in both management levels assess improvement of achievement to increase and expand Ruhul Islam quality, so that it would appropriate with development planning, conduct supervision, and evaluation on activities to improve Islamic working ethos. Related parties conduct the supervision process through questionnaires for the employees' customers that are using their services and the leaders as work observer. The obtained data will further become valuable indicators to assess institution's achievement of accomplishment. The purpose of applying this supervision process is to gain a complete information about condition and improvement of the employees' working ethos. Meanwhile, the assessment is done to measure the effectiveness and conformity of these Islamic working ethos activities.

Furthermore, the leaders in this institution are obligated to fulfill various requirements that act as indicators of Ruhul Islam application. The leaders, which are also lecturers, so far have been able to maintain their performance and meet the minimum requirement of an on-time lecturing process, and create a conducive, adaptable, and 
renewable learning environment through internal seminars as one of study program's agenda. An on-time lecturing process is a process where the leaders can deliver lecturing materials similar to previous meeting frequency and the ability to utilize their working hour optimally. The lecturers' achievement in this subject is quite decent because it is scarce to find an incomplete course due to lecturers' late arrivals. Furthermore, the lecturers usually arrive in their class earlier than the students do, especially in early morning classes.

Another effort which has been done by the leaders on both lines to insert Islamic values in their lectures is by including correlation between various subjects with many Islamic values. For example, connecting marketing materials in marketing classes with multiple ways of Islamic marketing. Some of the lecturers, which are also middleline and first-line leaders, always convey their lecture with good manners, such as practicing and habituating the students to use proper language although it is a nonformal language, optimize learning time by arriving and finishing their lectures on time, and achieve material and meeting frequency target.

The success of sharing Islamic-valuesinserted knowledge has brought a supportive learning environment and more interest from the students to participate in the lecturer's classes. Besides that, the lecturers are also able to adjust themselves to the development of their daily life, and it is easier for the students to adjust their way of thinking to the current knowledge and technology development level. These later activities will be able to realize the distribution of Islamic values inside the concept of Ruhul Islam effectively, so it would seep through every aspect of this institution and improve employees' Islamic working ethos in the educational institution.

With this achievement, the middleline and first-line leaders are successful in proving that they have become a good example for the employees and encourage the emergence of employees' spirit to participate by providing their best in work to help the institution achieve its goals. The employees' reluctance to arrive late, unable to finish their work in time, or to be considered slow in doing their job supports the realization of this encouragement. Besides that, the employees' inability to do their job will bring a bad impression for the leaders who have the authority to exchange employees with low working reputation.

This identification shows that the drive for the employees to apply Islamic working ethos has come internally to optimize their function as a part of the institution by making sure that everything they do is ideal and in line with the institution's standard, and also externally from the leaders. Based on the findings, we can say that the leaders in this high education institution play a significant role in maximizing the employees' potential and emerging employees' awareness internally and externally to give their best effort for this institution. Despite their selfawareness, the employees still require a direct supervision from the leaders because there is a small indication that employees' performance could experience degradation if one of their role models, the leaders in both management levels, is not presented at the office or loosening their supervision toward the employees.

A better supervision of the employees will increase the probability of Islamic work ethos success. The result of long-term supervision can create employees' work habit that would transform into a positive working culture. On that level, the employees would have a positive impression about their workload, or at least taking it as a pleasing thing to do. By the time, the employees will not take their job as a pressure or necessity and automatically increase their will to do the best they can. The leaders also contribute to the construction of the employees' positive behaviors by utilizing non-verbal languages.

One of the best examples is by displaying posters on how to get in touch properly with your supervisors or employers using short message service, starting from Islamic greetings usage, a brief and compact message formation, and an adequate and not excessive gratitude. This type of behavior construction will also bring positive attitudes from the leaders as a form of their responsibility as concept makers and a sort of rule enforcement. This concept brings positive impact on the formation of Islamic work ethos both on employees and the leaders.

As indicated through this research, we can state that Islamic work ethos in this educational institution exist due to the existence of Islamic values. These values are Siddiq or the employees' honesty; Amanah that contains loyalty, obedience, 
and responsibility of the employees; Tabligh or the employees' cooperation; and Fathonah or the high level of employees' initiative and accomplishment.

The formation of Islamic work ethos cannot be separated from the role of the leaders. It shows that Islamic work ethos encouragement comes from the middle-line leaders by utilizing their legitimate, referent, expert, and reward power. However, amongst the middle-line leaders, the utilization of legitimate power is more dominating than the other powers. Differ from middle-line leaders, the first-line leaders prefer to utilize expert and referent powers by setting exemplary figures for the employees. The distributed legitimacy from top leaders supports the leaders in both lower management levels, to be able to form various regulation and delegation systems that would help them improve Islamic work ethos.

Without the presence of supportive atmosphere, the effort of work ethos improvement will not be able to reach the optimum level. The implementation of various activities that includes Islamic values and involves the employees such as routine Islamic studies, pre-employment training, and proper service training in Islamic perspective is enhancing the strength of employees' Islamic work ethos.

\section{Conclusions}

This research reveals that Universitas Islam Bandung Post Graduation Program employees' Islamic work ethos is at a decent level. The factors that create this condition are the implementation of Ruhul Islam in their work life, which also supported by the leaders on both lines. Middle-line leaders play their role by utilizing their legitimate, referent, expert and reward power. Meanwhile, firstline leaders apply their role by using their expert and referent power. The leaders are also playing a significant role in the effort of Islamic work ethos improvement by manifesting themselves as exemplary models that implement Islamic values in almost every aspect of their work life.

Ruhul Islam has become an essential guideline for the institution to construct the employees' work mentality. The form of the employees' work mentality is the existence of Islamic values characteristics, which are Siddiq, Amanah, Tabligh, and Fathonah. The decent level of Islamic work ethos in this institution has been able to optimize employees' performance and increase the probability to achieve its goals as an Islamic based educational institution.

Along with the improvement of employees' Islamic work ethos, it is important to enhance Ruhul Islam application even further to reach goals that are currently unreachable. This will be simpler if the institution can consistently organize various Islamic activities that have a strong connection with work ethos in Islamic perspective. This condition will further sharpen the employees' understanding and effort to give their best in their work consistently, not only to fulfill their economic needs but also as a form of worship.

Even though this research has been succeeded in revealing engaging findings of middle-line and first-line leaders' role in the formation of employees' Islamic work ethos, there are several limitations in this research where improvement is possible. The first weakness is that this research only focuses on one Islamic based educational institution, which is Universitas Islam Bandung PostGraduate Program. Because of that, it only pictures a limited employment scope. The development of this research is available by expanding the sample of this research into several Islamic based educational institutions so that the result will be widely applicable.

Furthermore, the samples are only employees working as administrative officers, so that the other employees outside the department are not involved in the mapping structure. That is why in-depth research in the similar topic to optimize the output is highly recommended. Besides that, a verified-descriptive research is critical to be able to verify the significant role of middleline and first-line leaders in the formation of employees' Islamic work ethos and to produce an accurate Islamic work ethos model by using statistical verification.

\section{References}

Aziz, Amin. (2008). "The Power of Al-Fatihah", Jakarta Selatan: Pinbuk Press and Jakarta Selatan: MAA Institute.

Badriyah, Nurul and Noermijati (2015). Social Competence, Human Capital and Entrepreneurial Success (A Study on the Owner of Fish Trading Business), Asia-Pacific Management and Business Application, Vol. 3, No. 3, pp. 182-196.

Baldwin, Timothy T., Bommer, William H. 
and Rubin, Robert S. (2013). "Managing Organizational Behavior, What Great Managers Know \& Do", Second Edition, New York: The McGraw-Hill Companies, Inc.

Daft, Richard L. (2012). "New Era of Management", Tenth Edition, United States: South-Western, Cengage Learning.

Dewi, Yuliana and Rachmawati, Riani (2014). Leadership Development Experiences or Women Leaders in State-Owned Enterprises in Indonesia, The South East Asian Journal of Management, Vol. 8, No. 2, pp. 167-181.

Diefenbach, Thomas (2015). Inclusiveness and Exclusiveness of Japanese-Style Management Abroad - Some Evidence from Southeast Asia, The South East Asian Journal of Management, Vol. 9 No. 1, pp. 52-69.

Elgelal, Kamel Saleh Khalifa and Noermijati (2014). The Influences of Transformational Leaderships on Employees Performance (A Study of the Economics and Business Faculty Employee at University of Muhammadiyah Malang), Asia-Pacific Management and Business Application, Vol. 3, No. 1, pp. 48-66.

Hasan, Muhammad Tholchah (2005). "Dinamika Kehidupan Religius", Ed: Moh. Irfan dan Mastuki, Jakarta Utara: PT. Listafariska Putra.

Lauselang, H., Tang H.M., Hamdat S., and Demmalino E. (2016). Study on Economic Actors Work Ethos Salafi in Ambon (an Anthropological Study), International Journal of Scientific and Research Publications, Vol. 6, No. 4, April 2016. Retrieved from (http://www.ijsrp. org/ research-paper-0416/ijsrp-p52107. pdf). Accessed on February 6 2017, west Indonesian time.

McShane, Steven L., and Von Glinow, Mary Ann (2015). "Organizational Behavior Emerging Knowledge, Global Reality", Seventh Edition, United States: McGrawHill Education.

Mihrez, Abdo-Alaziz H.E. and Armanu (2014). The Importance of Leadership Behavior and Motivation in Creating Employee
Performance: (A Study at the University of Brawijaya), Asia-Pacific Management and Business Application, Vol. 3, No. 2, pp. 86-105.

Newstrom, John W. (2015). "Organizational Behavior: Human Behavior at Work", Fourteenth Edition, New York: McGrawHill Education.

Nida, Fatma Laili Khoirun (2013). Peran Kecerdasan Spiritual dalam Pencapaian Kebermaknaan Hidup, Konseling Religi: Jurnal Bimbingan Konseling Islam, Vol. 4 No. 1, pp. 185-200.

Possumah, B. T., Ismail, A. G., \& Shahimi, S. (2013). Bringing Work Back in Islamic Ethics, Journal of Business Ethics, Vol. 112, No. 2, pp. 257-270. (doi: http:// dx.doi.org/ 10.1007/s10551-012-12461). Accessed on 5 September 2016, 09:52 west Indonesian time.

Putri, Mentari Adriaeni and Gustomo, Aurik (2012). Analysis the Effect of Emotional Intelligence on Performance Through Leadership Style and Organizational Culture as A Moderator, Indonesian Journal for the Science of Management, Vol. 11 , No. 3, pp. 250-268.

Robbins, Stephen P. and Judge, Timothy A. (2015). "Organizational Behavior", Sixteenth Edition, United Kingdom: Pearson Education Limited.

Schermerhorn, John R. and Bachrach, Daniel G. (2015). "Introduction to Management", Thirteen Edition, International Student Version, Singapore: John Wiley \& Sons Singapore Pte. Ltd.

Sumual, Tineke E.M. (2015). Pengaruh Kompetensi Kepemimpinan, Budaya Organisasi terhadap Kinerja Pegawai di Universias Negeri Manado, Mimbar Jurnal Sosial dan Pembangunan, Vol. 31, No. 1, pp. 71-80.

Tasmara, Toto (2004). "Membudayakan Etos Kerja Islami", Jakarta: Gema Insani.

Yuningsih, Ani, and Mulyana, Dadan (2017). Communication Pattern and Skill of Leaders in Private University Management, Mimbar Jurnal Sosial dan Pembangunan, Vol. 33, No. 1, pp. 166-173. 